\title{
Translation as Episteme: Two Biblical Translations and the Role of Intellectuals
}

\author{
Etienne Rassendren *
}

\begin{abstract}
The article explores the inter-relations between episteme, ideology and knowledge in biblical translations and the underlying historical and intellectual questions that emerge. Through four narratives, drawn across differing timelines, this article maps the implications of theological and temporal power. Besides, it is also argued for how translations are sites of transgressions that eventually shape knowledge and impact epistemology. In conclusion, the article argues that Jerome and Wycliffe represent the role of public intellectuals and the dissident lessons of history.
\end{abstract}

Keywords: Translation, Episteme, Ideology, Knowledge

\section{Introduction}

In the context of the European Renaissance and Reformation, the place and position of biblical traditions were critical to both religion and culture. They became central concerns of people, both lay and ecclesiastical, as varied interpretations impacted society variously. With Caxton's printing press and the distribution of literacy, meaning-making concerning biblical texts conflicted with cultural-political hegemonies and dominations. Biblical interpretation as the clerical privilege would be soon dislodged by

*St Joseph's College, Bengaluru, India, erassendren@gmail.com 
cultural struggles between theological orthodoxy and intellectual liberalism. At stake was the power over the 'book' ${ }^{1}$ that fostered coercive hegemonies regarding knowledge. Ecclesiastical power posited 'forbidden' knowledge, as reason for the 'fall' of man (Milton, 1667) ${ }^{2}$-and forbade free circulation of the Bible in order to prevent heresy. Except when sanctified by church dogma or by ritual, the biblical texts themselves were considered far too rebellious for common folk, and overly dissident for the comfort of religious or secular authority. Just owning the bible was perceived as a grave sin, even a legal crime, inviting not only ecclesiastical reprimand but often public punishment. Common folk were traumatised by imprisonment or worse still, were burnt at stake. The real interest was epistemic control (Foucault 1989a, pp. xvixxvi) over dominant textualities of faith; indeed, over "ways of seeing" (Williams I989a, pp. 3-14) the assemblage of texts called the Bible. In fact, homogenising biblical textuality enabled moral and religious regimes to supersede secular realms. In other words - in a Foucauldian sense- 'conditions' under which knowledge of the divinity of Christ or the concept of God was established was determined by critical selection from a wide range of biblical texts that were in circulation at that time. Hence, any selection of the 'apriori', the ancestry, the archaeology, even the historicity (Foucault 1989a, pp. xvi-xxvi) of biblical texts was grounded on interpretative structures, chosen by an exclusive club of nobleman and clerics under the banner of the Holy Roman Empire working out of Constantinople. Such selective interpretative framesdifferentiating between good and evil-rejected inclusivivity and expanded approaches to religious knowledge and belief produced by common folk. After Nicaea (Encyclopaedia Britannica, p. 325) and its politics thereof, any episteme that provided new ways of seeing the world, and fresh ways of producing knowledge-employing alternative interpretative structures - about biblical texts, conflicted with the exegetic control of European schoolmen. This epistemological conflict-this conflict over ideas-exposed the protracted intellectual and cultural struggle between the hegemony of textual control and the counter-narrative of liberating textuality, 
regarding the Bible and its dissemination. These struggles eventually shaped the nature of the European Renaissance.

The fear that liberating biblical interpretation might unleash discourses of disobedience and emancipation forced both temporal and ecclesiastic power to foster epistemological control over about biblical texts. This approach to knowledge-creation enhanced secular and ecclesiastical governmentality (Foucault 2007b, p. 144) that kept subjects, in slavish loyalty to temporal and ecclesiastic nobility. This authority-subordination system further enabled the universal Church's self-preserving imperative that included hermeneutic regulation over biblical texts. That only the church, meaning its powerful men, could impose ways of seeing the world in biblical terms, created not only local discontent but also wars between countries and empires. Consequently, the distribution of Christian knowledge, through the biblical texts, remained circumscribed. Reading independently, biblical traditions was suspect and hence censored. Since only theological instruction mattered, questions about the true function of religious knowledge for humanist insight were silenced. Nuanced intellectual and spiritual interpretation was both abhorred and punished. Christian practice remained ritualised. The church recuperated pietisms rarely grounded in the biblical texts themselves. This systematic control over knowledge soon encountered serious dissent, which unravelled differing ideas that impacted knowledge-formation eventually.

Indeed, intellectual control was paradigmatic of ecclesiastical, political and cultural thinking, in fact of all knowledge in Europe between the rise of Constantinople, in the Holy Roman empire, through the Council of Nicaea into the birthing of the Holy See. These institutions favoured Holy Roman Emperors, ranging from Spanish Conquistadores and the French Dauphins, to the English kings and their vassals. Europe thus endured the terrifying Dark Ages that traversed between late antiquity and early Middle Ages, when both church and empire combined to produce intellectual fear and political violence. Not until the Renaissance, roughly the period beginning in $15^{\text {th }}$ century, did the glimmer of new learning 
and free knowledge determine significant epistemological change for society at large. The politics of biblical translation belongs in this ever-altering but terrifying context.

Biblical translation and its commentaries prompted many significant historical, cultural and religious discontinuities; chief among them was transforming Christianity into the new humanism, wherein European Renaissance engaged in violent struggle with orthodox power. Though translation in the Renaissance was fostered, and vernacularisation became common, it was always accompanied by severe epistemological violence and political repression, as the Hussite heresy (Odložilík, 1929, p. 644) testified. It invoked both suppression of knowledge (p. 636) and the burning at stake of Jan Huss (p. 639) and his followers (p. 639).

In the rest of this article, I wish to unpack here the struggle with emerging Christian knowledge and its implications for biblical translations; and also comment on the ideological frames implicated in and the historical-cultural forces impacting on the translation of biblical texts. I will also attempt to conceptualise the role of the public intellectual and expose the profoundly political nature of the agenda of biblical translations and the politics of its resistance.

\section{Conceptualising translation and its implications}

Instead of the usual re-statement of definitions about translation, let me invoke four narratives, stories of great insight, which depict the function of translation in both ancient and contemporary society. Envisioning the framework in this way reflects the narrative and its design in a manner which mark the epistemological historicity of this analysis, not the absurd "scientificity" (Foucault 1989a, p. 6) of mythos, the paradigm ascribed to reflections of biblical traditions. This narrativisation is different because of its "imaginary" (Lacan 1977); i.e. the image-making agency and ideational struggles which frame these stories within discourses of power. In Lacanian terms, it implies how imagined referencing constitutes self. This shift, I mark here, is profoundly historical for it dis-embeds a "screen- 
discourse" (Foucault 1978c, p. 53) that hid the ideational and ideological histories of pre-Renaissance European history.

The first story is that of Averroes, philosopher and Islamic scholar, who lived in the great cusp of the European Dark Ages and Middle Eastern scholarly progress. Ibn Rushid, latinised by the intellectually inadequate Europe, as Averroes, was a scholar of Aristotle's "Poetics" (Aristotle, 1974). Famous for his line-by-line commentary of Aristotle, Averroes was a public intellectual, speaking without inhibition or self-censorship for some radical ideas about faith and logic. Averroes argued for three major intellectual premises on which all philosophy should be based, which, he claimed, even the Qur'an suggested: first, the physical world existed alongside God, although God gave its creatures shape and life; second, only souls survived after death and bodies did not, though souls might find new bodies beyond life; and third, thinking and intellect were outside the soul and were collective not individualistic experiences. Three ideas emerging from the analysis were: a) God did not precede the world but was simultaneous with it and so creation was only transformation from one being to another; b) the temporality of the body was matched by the eternity of the soul and c) knowledge was always collective. Indeed, Averroes anticipated much of the current debates. The evolution vs. creation polemic; the body-natural and the soul-spiritual divide; and above all, plurality vs. uniformity of knowledge polemicthese complexities and paradoxes are questions that metaphysics raises (Pasnau, 2011) and epistemology specifically interrogates even today. Hence, Averroes was ahead of his time, and indeed emphasised epistemic variety, including contested episteme, for exploring knowledge. But, the combined forces of the Church and state silenced such possibilities, for fear of losing power over intellectual and material life.

Averroes encountered trouble for his views and for emphasising "mantiq" (logic), as the ground for knowledge. For the Caliph in Islamic Spain, it was too heretical for the progress of Islam as a world religion. Averroes was banished from his native Cordoba, 
only to win back the Caliph's 'favour' in 1195, with the retreat of fundamentalist Islam.

This narrative throws up some crucial ironies. By the time Averroes arrived, Christendom had been established. It was also challenged, because of a decadent Byzantium and later the powerful Ottoman Empire. By $900 \mathrm{CE}$, the centres of philosophy had shifted from Hellenic Europe to Islamic Mediterranean (Pasnau, 2011). The rigidities of Judaism, Christianity and Islam caused loss with the systematic destruction of so-called 'pagan' knowledge. But despite all, many anti-establishment ideas crept into European learning, through subversive translations of books, including biblical ones, facilitated by uncompromising scholarship. Many Arabic-Persian scholars systematically translated Greek masterpieces, including Aristotle and Plato; they made assiduous notes, worked commentaries and disseminated them to their students. Most scholars knew that Plato and Aristotle were simply unobtainable in the original, because of book-burnings, but translations in the Persian-Arabic were. As for Aristotle, it was Averroes' commentaries that were avidly re-translated, in the 11CE, after the fall of Toledo to Christian conquerors, (Wolfson, 1961, pp. 373-392) not into Greek but into Latin, as that had become the scholarly language of the current Empires. Hence the episteme, the assemblage of emerging ideas and its history, was inflected, not just by European Hellenism, but also by Persian-Arabic thinking. Therefore, liberal Islamic thought shaped European religious and aesthetic tradition indeed.

In this complicated intellectual environment, Thomas Aquinas conversed with Averroes' followers in Paris, He was mandated to install the church's "ex nihilo" (p. 376) facet of the biblical creation story and to establish intellectually and institutionally, both the dogma of resurrected bodies and the inevitability of individual intellectual habit (Pasnau, 2011). Aquinas overturned Averroes' argument about creation, the human body and the collective intellect effectively establishing Christendom. Aquinas' episteme of a-priori creation and human individuality successfully replaced Averroes' paradigmatic of simultaneous creation and collective 
sensibility, making Hellenic-Christian thought dominant in the Renaissance. Averroes anticipates Jerome's struggle with episteme and interpretation, for his Latin Vulgate and Wycliffe's for his Lollardist Bible. In other words, Averroes conceptualised what both Jerome and Wycliffe practised.

The notion of temporality in translation is instructive, because authenticity in biblical traditions was absent, the book being translated ad nauseam, from Hebrew to Greek, as in Hebraica Veritas to Graeca Veritas (Semple, 1965, p. 233 \& 232). With Averroes, one discovered translation as epistemology, meaning a manner of seeing the world and the text, knowledge and tradition, language and ideology. But the powerful Thomas Aquinas literally silenced Averroes' contributions to Aristotelian studies (Wolfson, p. 382), thereby destabilising its relevance in Christian exegetics. Though biblical interpretation was shaped by Persian-Arabic Aristotelian studies, the church rejected it.

Translation of biblical texts transacted not between languages alone. They mediated cultural exchange between Mediterranean languages, Greco-Roman traditions, and European vernaculars. The earliest biblical translations were cross-bred by both Christian Greco-Latin-Hebraic traditions and Islamic-Persian-Ottoman Arabic significations. The Wycliffite Bible certainly could not escape this cultural and intellectual interface. For instance, Wycliffe's support of consubstantiation back-looped Averroes' philosophical injunctions retrospectively.

The next story from John Dominic Crossan's The Historical Jesus: The Life of a Mediterranean Peasant (1992) suggests that in recording Jesus' Beatitudes, Luke and Mathew employed two differing beginnings. The Q Sayings-Gospel (p. 270), most credible of biblical sources, identified the following differences:

Blessed are you poor [ptochoi] for yours is the kingdom of God (Sayings Gospel Q, 1Q: Luke 6:20) and,

Blessed are the poor in spirit [ptochoi], for theirs is the Kingdom of heaven (Sayings Gospel Q, 1Q: Mathew 5:3) (p.270) 
The above references expose the semiotic and symbolic shift in translation. Luke maintained the material connotation of poverty, its reference to the really downtrodden, beggarly, poverty-stricken people of Israel/Palestine, while Mathew added the spiritual aspect. Mathew thus altered the connotation of the 'poor' spiritualising the highly this-worldly experience of poverty into an other-worldly transcendence. This interpretative felicity, Crossan calls, "Mathew's gloss" (p. 270) and underlines the evangelist's religious didacticism. The language of address, the textualising of Jesus' sayings and Mathew's authority over his sources induced semiotic jugglery altering meanings.

This connotative mischief apart, other liberties like replacing Greek referents with more appeasing spiritualist word-formation, distorted meaning-generation. Moreover, absolutist authority over the histories of biblical texts reduced meaning-making into ideological prescription. The 'poor' of the Beatitudes, was confused with "Penia" (poverty) while the more radical Jesus referred to "Ptocheia" (beggary). According to Crossan, penury (penia) was an easier condition than beggary (ptocheia) (p. 271). Crossan invoked Aristophanes" "Plutus" to show the difference between penury and beggary (p. 270); the former, suggesting 'material lack', and the latter, downright impoverishment. Penury meant lacking surplus and the "degree of leisure and independence" that befit "the life of a gentleman" (p. 271), while beggary suggested destitution and starvation (p. 271). Crossan writes:

Such was the Greek term ptochos, a word suggesting 'one who crouches' and so a 'beggar'... penes was not... Penia meant the harsh compulsion of toil, whereas the pauper, the man who was altogether without resources was normally called a ptochos, a beggar, .... p ptochos was on the margins and ...was someone who had lost many or all his family...He often was a wanderer, therefore a foreigner...could contribute very little or nothing at all...(p. 272)

The reference to the marginalised, the outsider, the impoverished, the refugee, the complete 'other' could only be replaced by a facile 'gloss' because of the evangelist's ideological determination. I argue that the desire to appease tyrannical regimes diluted the otherwise emancipatory prophecy against this-worldly discrimination. In 
ideologising episteme, biblical glossing became the mouthpiece of the powerful in Church and state.

The third narrative is embedded in Goethe's idea of world literature in the 1820 's. In post-enlightenment Europe, when nations lived by their identity politics, the idea of world literature was doubtlessly revolutionary. It meant, as Goethe describes, an "inevitable" transaction between human beings (Goethe, 2000a, p. 2) across societies. "[T]ranslation" remained key to this dialogue (Goethe in Gearey 1986b, p. 227). Writing to Thomas Carlyle, Goethe emphasised that "the connection between the original and the translation" was ultimately "the relationship of nation to nation" (Goethe 1949c, pp. 349-350). In this exchange between languages and cultures, texts were "reborn" (Goethe, p. 22). Thus, translation practice transcended politically bounded societies and shrunk the world. Orthodox ideas of "native land" were irrelevant, the world itself becoming an "expanded homeland" (Goethe in Gearey 1986b, p.227).

Translation practice embraced all people of the world and reinvented cultural texts. But translation russified too (Anderson, 1991, p. 86), making societies mono-lingual through languagehierarchies. Binary oppositions between so-called master-languages and slave-languages came about. Consequently, many languages were either rejected or silenced. Despite intellectual avowals, the rise of superior/inferior language-hierarchy totalised the uses of translation, privileging dominant languages over subjugated ones. The cosmopolitanism that translation practices had promised was lost to the cultural politics of imperialism and colonisation which would stratify the otherwise democratic matrix of languages. The Anglicisation of Africa and Asia remain remarkable examples. Thus, translation mono-lingualised people, setting up nationalities, and producing contradictorily nations and empires. As such, translation raised ontological questions about the belonging of people to a particular religion, a church, a state. It often caused irredeemable discord. In surrendering to identity politics, epistemological shifts became centralising forces and translation practice became the method to dislodge languages and 
subjectivities at will. This double-edged possibility of translation practice posits an epistemic grid that is conflictual; one ideologises self-serving subjectivities and the other reframes collective social consciousness. Consequently, epistemology merged with ontology in translation practice. The Latin vulgate, for instance, distributed biblical texts across cultures, but brought varied European languages and cultures in the Holy Roman Empire under the Holy See.

The final story belongs to Gayatri Chakraborthy Spivak, much celebrated feminist-translator of the 20th Century. Spivak translated particularly gendered subaltern voices, otherwise living within the languages of the margins. Despite their emancipatory potential, these provocative texts, remained unrepresented, i.e. excluded everywhere. They were the unspoken subaltern-Dalit/tribal women, brutalised by political authority, or omitted by bourgeois ideology (Spivak 1988a, pp. 217 \& 313). Spivak translated these complex, often hidden subaltern texts, from local languages she knew well.

Spivak critiqued Walter Benjamin, (Spivak, 1988b) for depicting host languages as languages "of authority". Benjamin's argument emphasised unnecessary originality to host languages, which prevented translations into languages of "subordination" because subjugated languages dislodged the presumptuous integrity of master-languages in translation. That is, if one translated from Bengali into English, Bengali should lose itself for English accuracy thereby installing English language superiority over others. Spivak named this imperial tendency "translation-as-violation". By contrast, there was "translation-as-freedom-in-troping" (Spivak, 1999c, p. 163). Simply put, some translations released texts and their meanings freely into other languages and cultures. Thus, vernacularising sacred-texts exemplified translation as freedom, whereas, sacralising texts violated meaning-making. All translations must aim to free content and meaning, interpretability and distribution, so that knowledge is democratised. This mode becomes translation as hermeneutics, a way of interpreting texts and their worlds, while its episteme produces signification. 
None of these narratives is about the two translation projects investigated in this article. But they characterise the politics of Biblical translations undoubtedly. If Averroes and Crossan refer to the culture-conflicts between Greek, Latin and Hebrew, they also explain Wycliffe's struggles with both literality and intention. By contrast, Goethe and Spivak disclose the ideological and hermeneutic assumptions of the translation projects themselves. Thus, there are four major conceptual frames of translation theory and practice, which these stories propose. They are translation as a) episteme, b) ideological determination c) identity-construction and d) signification.

\section{The first translations}

The first biblical translations were sites of re-membering (Spivak, 1985; Parry \& Benita, 2004)3. The conflict between the Masoretic texts and Greek Septuagint remained legendary. The birth of the Greek Septuagint was mythologised in popular memory by the "Letter of Aristeas" (Metzer, 1993, p. 37)-which Ptolemy II's commissioned - inviting Jerusalem elders to translate Hebrew scriptures into Greek. The translations turned out identical and everyone believed God inspired them. Later scholars claim these were Alexandrian in style and hence not of 200 BCE. They were interpolations the Bishops legitimised so that Hebrew/Aramaic people distanced from their language may understand their scriptures in local Greek (p. 39). However, the order of books changed and the explanations; Targuns, (p. 42) conformed to current hegemonies, facilitating other translations such as the Peshitta, in Syriac (p. 44). Thus, empires mediating translations established homogeneities that legitimised their tyranny, translations themselves creating authority and control. So, Biblical translation established rather than resisted repressive secular politics. As Church and Palace consolidated power, biblical exegetics mobilised by epistemological rigidities, structured ideological and ontological unity, which brutalised congregations and subjects alike, thereby instituting cultural political controversies. 


\section{The Latin Vulgate and its controversies}

The next controversy emerged while translating biblical texts into the Latin Vulgate. By 300 CE, Latin became the empire's dominant language. Greek though extensively spoken and written, became alien to people. It was known only for its sophistry and its unintelligible rhetoric. The Septuagint remained important but the clamour for a Latin translation grew sizeably. Biblical knowledge, it appeared, could be better served if the bible was in Latin. Jerome was commissioned by Pope Damasus I to undertake translation work. Though 27 Latin translations floated around, as "Vetus Latina" (Metzer, 2005b, p. 72), church congregations resisted them. Besides, the Greek and Syrian orthodoxies suspected the Roman Church, because of theological dissonances over Jesus' divinity and papal authority. Mediterranean and European church patriarchs fought over equal distribution of money and power. Schisms were strong; and alienating anybody anywhere would fragment the church further.

Jerome began translating the authoritative Septuagint into the Latin vernacular, in this context. The gospel translations were received with great delight by both congregation and leadership. But, all hell broke loose soon, when Jerome translated Old Testament stories from the Hebrew texts. Jerome's knowledge of Hebrew and his phraseology was doubted though he assiduously learned Hebrew in the Mediterranean monasteries. He consulted Hebrew scholars, so that all disputation might end. But congregational division caused acrimony over his translations. Consequently, Rome was troubled over the erosion of its papal authority.

Chief among Jerome's critics was Augustine of Hippo, scholar of the Roman church and master of languages, literatures and biblical exegetics. Augustine and Jerome exchanged letters/epistles that interrogated the veracity of each one's intellectual and religious propriety. Augustine's objections concerned the "high authority" of the Septuagint, problems over "Hebrew syntax", the inexactness of meaning, regarding the book of Job and the "differences" between the "Latin ....and Greek Churches" (Augustine \& Jerome 18901900). Jerome's acerbic repartee cited the inappropriateness of 
Augustine's arguments: fallacies in understanding the Septuagint and Latin Vulgate. Jerome argued that he amended the Septuagint on behalf of the Word of God, the people and religious scholarship (Jerome, Letter, 112). Augustine's City of God (Augustine, 1887, p. 426) unflinchingly emphasised the Septuagint's primacy calling Jerome's translation linguistically erratic and culturally divisive. Jerome, despite disputations, continued to invoke Hebrew texts for authenticity.

Jerome claimed, that he corrected Greek translations, so that an authentic voice might emerge. Besides, he was only filling up gaps between the New Testament and the Old Testament stories (Semple, 1965-66, pp. 227-43). Quotations from Old Testament ascribed to the apostles were not obtained in Septuagint's Old Testament; the errors were explicit (p. 237). Jerome blamed "lazy copyists" (Semple, 1965-66, p. 232), for them.

Jerome was not innocent either. He also changed phraseology, ironed out tone, wrote explanatory prefaces, consolidated meaning but took full responsibility (Semple, 1965-66, p.233). His Preface to the Book of the "Kings" asserted his linguistic authority over biblical scholarship to the chagrin of many.

Jerome performed what Crossan called the evangelist's 'gloss'; the Latin Vulgate was full of them. But the polemic between Augustine and Jerome concerned the unity of the church, not just the appropriateness of translation or the meaning of the biblical texts. Both desired epistemic control, the one, in supporting the Septuagint and the other, establishing linguistic change. Plurality was always suspect, because it spiked denominational fragmentation. Though Jerome employed translation to liberate meaning he suffered disrepute and marginalisation. Jerome's infamous Latin Vulgate gained respect only two centuries later. But, even that historical watershed was short-lived for the Latin Vulgate was replaced by European vernaculars. The intellectual journeys of translation practice began again. 


\section{Wycliffe and biblical translations}

Nearly a thousand years after Augustine, John Wycliffe and the Wycliffites long associated with Lollardy, a movement of 14th century rebellious clerics and lay critics, sought reform within the Roman church. The Lollards considered their clergyman depraved, authoritarian and exploitative. The Roman Church sought after absolute control over the spirituality of people and used subtle processes to suppress 'true meanings' in biblical texts. The local cleric owned the hermeneutic to mediate God's good word. The village pastor rarely owned the Greek or Latin Bible; yet he had doctrinal authority over the holy book. (Knapp, 1971, pp. 713-72). He changed everything into moral instructions concerning sin; coupled with ignorance he forced material extortion as penitence. Exorbitant tithing for parish clergy; individual banishment and exile for intolerance; public flogging as penitence for disobedience; burning at stake for heresy and schism; and violent extortion of wealth - all made the local priest law unto himself. The alienation of the laity grew. Besides, the higher echelons of the church, its ecclesiastical nobility, yoked together church and state. Hence, church doctrines also defined the secular laws of empire, nation or protectorate. Thus, heresy and schism were legal crimes; and the sinner-heretic was also state criminal.

Wycliffe and his Lollards rebelled against these incorrigible tyrannies. They were educated men, passionately committed to Christian faith. Their ambition was to deliver the liberating meanings of the gospels to common folk. These were "poor preaching priests", travelling "barefoot...in long gowns of russet who "went around the country...preaching diligently to the people" (Aston, 1965, p. 35). Wycliffe and his followers were 'ascetics' coming out of Oxford living "pure and blameless" in "rude, dark, corrupt times" (p. 36). They had scholarly reputations and were the "ministry" with impeccable standards that evangelised diligently (p. 35).

Wycliffe's intellectual work however currently suffers suspect ascription and uncertain attribution, his scholarship shrouded in mystery (Fang, 2001). Yet the biblical translations-if only 
partially-into English, the Conclusions, nailed at St Paulanticipating Martin Luther's Wittenberg resistance-the Sermons on biblical hermeneutics and the General Prologue-he edited them. For his stubborn will and his intellect, Wycliffe became the "Morning Star" of the English Reformation (Aston, p. 24).

Wycliffe's intellectual effort was two-fold: a) to translate the Latin Vulgate into English and b) to evolve a hermeneutic of gospel meaning without clerical interference. When Wycliffe began translating the Bible, he had neither authorisation nor approval from clergymen of his time. But he had an indomitable spirit, a fierce sense of righteousness, and an equally ferocious moral compass. His Oxford education prompted him to contest ecclesiastical nobility, the church's absolutist regime and ritualised pietism. He hated the sale of indulgence, the luxury of clerical authorities and the repressive feudalism of clergymen. He strove to democratise the message of the gospel, share its liberating injunctions and energise people into true spirituality. He found local clerics compromising social transformation because of their presumptuous nature, their insufficient knowledge and their discreditable behaviour. Wycliffe desired that men and women know the 'gospel', in their native tongue. Hence, he chose to translate the Bible into Middle English, for common British folk, emphasising simultaneously his preeminent patriotism (Coxe \& Margaret, 1840, p. 233).He wrote extensively on the triangular relation between church, state and scripture. For him, the Church was subordinate to state and both were subordinate to scripture, but each must remain separate, not inbred into repressive apparatuses of power. Thus, Wycliffe struggled to democratise faith and distribute knowledge freely without church led inflections for self-serving monarchs. The translation that he used was not all his, but he supervised and revised much of the rest. Wycliffe certainly held "editorial and inspirational function" (Knapp, 1971, p. 714) and Wycliffites like John Purvey followed his insightful injunctions. Purvey soon became synonymous with revolutionary Christian discourse, and was associated with Wycliffe's General Prologue, his Conclusions and Sermons about gospel teaching (Aston, 1965, p. 46). 
Wycliffe and his associates employed two commonly accepted translation practices. One was one-on-one transliteration of words and meanings. This approach maintained "original thought" without risking alterations (Knapp, p. 714). The other was construing, a guessing game, which unearthed intended meaning (p. 714). These two processes delivered God's own meaning in England's native tongue.

Wherever literal meanings became obscure, the Wycliffites provided commentaries and sermons (p. 715). These interpretative frames caused controversy because they rejected the normative of the Roman Church (pp. 715-716). Thus, biblical translation encompassed epistemological alterity, which, as Spivak suggests, liberated the texts from the tyranny of established meanings. Thus, three main theological and philosophical arguments were served in the process: a) the relationship between God and Human could be established without mediation, b) the Bible and the gospel messages were signposts for all and translation was necessary so that the faithful understood and c) the Roman Church desired control over gospel meaning only to exploit people.

Wycliffe and his Lollards are critiqued for inaugurating fundamentalist and literalist interpretations of the biblical tradition. But that is unfounded for Wycliffite translation style used "plain" language but explained figurative usage too. It rescued biblical meaning from orthodox mediaeval schoolmen and freed it from obscurantist rhetoric. The effort was more to uncover the embedded spirit of biblical texts than to literalise meanings (Ludin, 2008, p. 132).

The Lollard Bible came with the General Prologue, the Sermons and Commentaries. The supporting discourses established connections between word and meaning. There were four major kinds of meaning-orders disclosed: literal, allegorical, moral and analogical. The literal was always beholden to the rest. Hence, Jerusalem, when translated literally meant the Judaic city, but figuratively the "city" symbolised Mother-Church and the spiritual destiny of Christians (p. 136), immediately becoming metaphoric and allegorical. This underlines Crossman's depiction of the 
meaning-shifts from 'beggary to penury' in Mathew's gloss. Therefore, epistemic shifts were about literal meanings becoming connotative of God's intention. The common folk heartily embraced such intellectually astute and cognitively sharp readings as they inspired great hope, but clerical authority remained dissatisfied and scared because nobody anymore needed to teach biblical morality. With Lollard discourses and commentaries, believing Christians turned independent of clerical authority.

Wycliffe encountered another controversy concerning 'consubstantiation' and 'transubstantiation'. The catholic world believed-and continues to-in the actual transformation of the bread and wine into the body and blood of Christ. Wycliffe argued that the Eucharist could only be symbolic as there was no biblical corroboration. Moreover, transubstantiation implied "cannibalism", which was anti-Christian. Such belief was false and propagating it made Christianity morally bankrupt. These highoctane arguments earned Wycliffe and his followers the wrath of the Holy See.

The papacy declared Wycliffe a heretic and was exiled by the King (Aston, pp. 25 \& 26). He returned home in 1384 only to die there. His translation work was almost done then; his trusted preachers evangelised rigorously. Although discredited by Rome, Wycliffe's insights remained popular. Though interred on his death in the sacred cemetery of Church fathers, his body was exhumed and burned at stake, 44 years later. But Wycliffe, his thoughts and ideas, would shape Renaissance English history eventually (p. 24).

\section{Conclusion}

In conclusion, let me point first to the limits of my exploration. This is no comprehensive study of biblical translations. Such historical moments carry more. Yet Bible translations traversed different trajectories, including birthing the Armenian alphabet and its national identity (Zekiyan, 2005), while Ulifilas' Gothic translation energised Arian controversies (Pakis, 2008). Many other bibles were born during the European Reformation to controversy and violence. Thus, biblical translation was both ideational and 
ideological struggle for both translator and translation, marked by the politics of meaning-making.

Between Jerome and Wycliffe, translation projects became sites of transgression. Within Church-State conflicts, they became ideological encounters with power. If translation re-installed tyrannies of religion and empire, there would be no fear. Instead it dislodged cultural hegemonies and upset power structures. Its proponents were exiled, imprisoned or burnt at stake, their books censored or burnt. Besides, those epistemic breaks translation provided freed intellectual discursivity. For Jerome and Wycliffe, translation enabled meaning-shifts which in turn altered religious thought and insight everywhere, challenging religious and state despotisms. If Jerome strove to include common folk into larger collectivities through local Latin, Wycliffe cleansed biblical meanings to provide cultural identity to his people. Thus, freeing and distributing knowledge to common folk shaped the Renaissance, for that implied newer ways of seeing the world. It asserted the right to independent thinking and the respect for local languages. It destabilised elitism mediating epistemic shifts for Renaissance history and knowledge

How then are such intellectual projects relevant to current times? The stories of Jerome and Wycliffe are lessons in ideological and cultural dissent and exemplify the role of public intellectuals. They embody that spirit of conscience and the inalienable right to questioning injustice and inequality. In every sense, they constitute the very spirit of freedom, the right to disagree, and the effort to advance social and intellectual change. For Gramsci, the intellectual must provide organic knowledge and persuade rational thinking, based on critical humanist ethics for social transformation (Gramsci, 2004, p. 6). Foucault urged "shaking up habitual ways of working and thinking to dissipate conventional familiarities" (Foucault, 1990d, p. 265) to alter ways of seeing the world, not mobilise action; and for Said, intellectuals were quarrelling social critics, ceaselessly speaking for the "underrepresented and disadvantaged", dissenting with "dogma and orthodoxy" (Said, 1994, p. xv \& 9): all these representations describe dissidence which 
Jerome and Wycliffe embodied in history. They learnt hard and strong, shook up facile conformities and dangerously attacked intellectual and religious authority. In their time, as Said would argue, they spoke "truth to power" (p. iv).

\section{Notes}

1The term 'biblia' in Latin means the 'book'.

2The fall in "Paradise Lost". See J. Milton, Paradise lost: Book I (1667) Retrieved from http://www.dartmouth.edu/ milton/reading_room/pl/book_1/text.sht $\mathrm{ml}$ accessed 14 Sept 2016 web

${ }^{3}$ A term meaning memory as History. See Spivak, G. (1985). Three women's texts and a critique of imperialism. Critical Inquiry, 12(1), Autumn, 243-261 and Parry, B. (2004). Reconciliation and remembrance. In Post-Colonial studies: A materialist critique (pp. 179-193). London/New York: Routledge.

\section{Bibliography}

Arianism. New World Encyclopaedia. Retrieved from http://www.newworldencyclopedia.org/entry/Arianism on 26-1117.

Anderson, B. (1991). Imagined communities: Reflections on the origin and Spread of nationalism. London/ New York, NY/London: Verso.

Aston, M. Aston, M. (1965). John Wycliffe's reformation reputation. Past $\mathcal{E}$ Present, (30), 23-51.

Augustine. (1887). Chapter 42: Of the sons of Joseph, whom Jacob blessed, prophetically changing his hands. In P. Schaff (Ed.), A select library of the Nicene and Post-Nicene Fathers of the Christian Church. Vol. II St. Augustin's City of God and Christian Doctrine. Buffalo: The Christian Literature Co.

Augustine. (1887). Chapter 43: Of the times of Moses and Joshua the son of nun, of the judges, and thereafter of the kings, of whom Saul was the first, but David is to be regarded as the chief, both by the oath and by merit. In P. Schaff (Ed.), A select library of the Nicene and Post-Nicene Fathers of the Christian Church. Vol. II St. Augustin's City of God and Christian Doctrine. Buffalo: The Christian Literature Co. 
Augustine. (1887). Chapter 44: How the threat of the destruction of the ninevites is to be understood, which in the Hebrew extends to forty days, while in the Septuagint it is contracted to three.

In P. Schaff (Ed.), A select library of the Nicene and Post-Nicene Fathers of the Christian Church. Vol. II St. Augustin's City of God and Christian Doctrine. Buffalo: The Christian Literature Co.

Colwell, E. C. (1937). Slandered or ignored: The Armenian gospels. The Journal of Religion, 17(1), 48-61.

Council of Nicae a- Christianity 325. (n.d.). In Encyclopaedia Britannica online. Retrieved from https://www.britannica.com/event/Councilof-Nicaea-Christianity-325 on 6-10-2017

Crossan, J. D. (1992). Kingdom and wisdom - The historical Jesus: The life of a Mediterranean peasant. NY: Harper One/Harper Collins.

Coxe, M. (1840). The life of John Wycliffe. Columbus/ Gambier: Western Church Press.

Dunn, M. (2012). Intuiting gods: creed and cognition in the fourth century. Historical Reflections/Reflexions Historiques, 38(3), 1-23.

Frazee, C. (2007). Review: East and West: The making of a rift in the Church from Apostolic times until the Council of Florence by Henry Chadwick. Church history, 76(3), 611-612.

Foucault, M. (1978). In Scienta Sexualis - History of sexuality: An introduction (R. Hurley Trans.), Volume I. NY: Pantheon.

Foucault, M. (1889). Preface. In The Order of things: An archaeology of the human sciences. London/ New York: Routledge.

Foucault, M. (1990). In Kirtzman, Lawrence \& Sheridan, Alan (Eds.), Politics, philosophy and culture: Interviews and other writings - Michel Foucault. New York/London: Routledge.

Foucault, M. (2007) In M. Senellart, F. Ewald, \& A. Fontana (Eds.), Security, territory, population. New York: Palgrave Macmillan.

Goethe, W. J. (1949). In F. Strich (Trans.), Goethe and world literature. London: Routledge.

Goethe, W. J. (1986) In J. Gearey (Ed.), Essays on art and literature - Goethe's collected works (Vol. 3.). New York: Suhrkamp.

Goethe, W. J. (2000). In H. Birus (Trans.), The Goethean concept of world literature and comparative literature. CLC Web: Comparative literature and culture 2.4 . Retrieved from http://docs.lib.purdue.edu/clcweb/vol2/iss4/7 
Gramsci, A. (1971/2004). Selections from the Prison Notebooks of Antonio Gramsci. Ed. and Trans. by Q. Hoare E G. N.Smith. Hyderabad: Orient Longman.

Lacan, J. (1977). In A. Sheridan (Trans.) Ecrits: A selection New York: Norton.

Metzger, B. (2005). The text of the New Testament: Its transmission, corruption, and restoration. Oxford: OUP.

Milton, J. (1667). Paradise lost: Book I. The John Milton Reading Room Line 1. Retrieved from http://www.dartmouth.edu/ $\sim$ milton/reading_room/ pl/ book_1/text.shtml accessed 14 Sept 2016

Said, E. (1994). The representations of intellectual: 1993 Reith lectures. London: Vintage

Spivak, G. C. (1988). Can the subaltern speak? In C. Nelson \& L. Grossberg (Eds.), Marxism and the interpretation of culture (pp. 21-78). Urbana, Chicago: University of Illinois Press.

Spivak, G. C. (1988) Devi. In G. C. Spivak (Ed.), In other worlds: Essays in cultural politics. London: Routledge.

Spivak, G. C. (1999). Literature. In G. C. Spivak (Ed.), A Critique of postcolonial reason: toward a history of the vanishing present. Calcutta: Seagull.

Knapp, P. A. (1971). John Wycliffe as Bible translator: The texts for the English sermons. Speculum, 46(4), 713-720.

Lundin, R. W. (2008). Rhetorical iconoclasm: The heresy of Lollard plain style. Rhetoric Review, 27(2), 131-146.

Metzger, B. (1993). Important early translations of the Bible. Bibliotheca Sacra, 150, 37.

Fang, N. S. (2001). Translation, interpretation, and heresy: The Wycliffite Bible, Tyndale's Bible, and the contested origin. Studies in Philology, 98(3), 315-338.

Odložilík, O. (1929). Wycliffe's influence upon central and eastern Europe. The Slavonic and East European Review, 7(21), 634-648.

Pakis, V. A. (2008). Homoian Vestiges in the Gothic Translation of Luke 3, 23-28. Zeitschrift für deutsches Altertum und deutsche Literatur, (H. 3), 277-304.

Pasnau, R. (2011). The Islamic scholar who gave us modern philosophy. Humanities: The Magazine of the National Endowment for the Humanities, 32(6). Retrieved from https://www.neh.gov/humanities/.../the- 
islamic-scholar-who-gave-us-modern-philosophy online. Web. accessed 10-10-2016

Semple, W.H (1965-66). St. Jerome as a biblical translator. Bulletin, XLVIII, $227-43$.

Williams, R. (1989). Culture, democracy, socialism - Resources of hope. London: Verso.

Wolfson, H. A. (1961). The twice-revealed Averroes. Speculum, 36(3), 373392.

Zekiyan, B. L. (2005). The Iranian Oikumene and Armenia. Iran \& the Caucasus, 9(2), 231-256. 